\title{
Swedish institute sued for software piracy
}

Paris. The Karolinska Institute in Stockholm is being sued for software piracy by a Swedish company, Eurodex. The company is seeking SKr10.3 million (\$US1.6 million) in damages, and says it is taking the action because of frustration over the slow progress of a police investigation into the allegations.

This investigation began in June last year, when police, accompanied by Eurodex staff, raided premises of the institute in and around Stockholm. According to Eurodex, a search of 251 computers revealed that 90 contained illegal copies of StatView, a statistics and graphics package that it markets in Sweden for Abacus, a Californian software developer. The company says the software was also found on network servers, although it had not licensed any network versions to the institute.

"We are very surprised that the district attorney has still not made a decision [to prosecute], given that the evidence against the institute is so strong," says Deniz Özen, managing director of Eurodex. One company official says that police involved in the investigation feel that the institute has been "dragging its feet". He also claims the institute was tipped off about the raid, and that police found evidence of attempts to delete

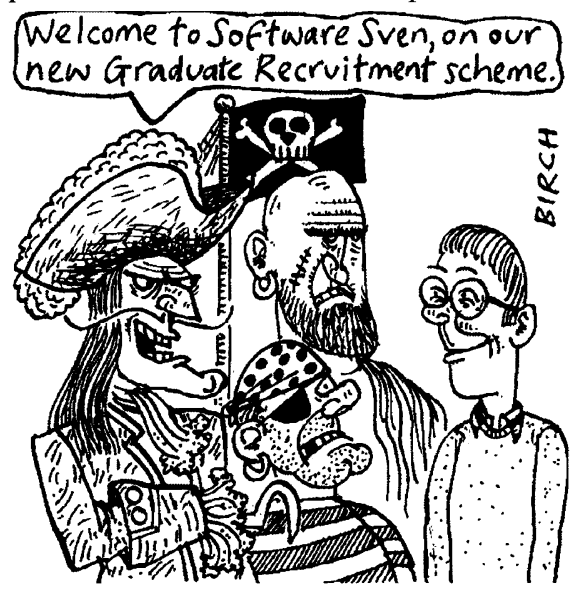

StatView and other software from computers. "Activity at the institute was very high on the morning of the raid," says the official.

But Hans Wigzell, the vice-chancellor of Karolinska, one of Europe's leading biomedical research institutes, says that it has cooperated fully with police. The case is complex, and its slow pace is therefore not surprising, he adds, pointing out, for example, that many foreign visitors to the institute bring their own software, which they may have licensed at home.

Sweden introduced piracy laws only five years ago, and software copied before and after that date must therefore also be distinguished, he says. An internal inquiry soon to be completed suggests that "nothing [may] come out of the police inquiry", he says.

Kent Madstedt, the regional prosecutor in charge of the investigation, agrees that establishing that illegal activity took place is less straightforward than Eurodex claims. The company's estimates of the extent of piracy are based on the discrepancy between the number of software licences returned by researchers (18), and the number of packages found, he says. But not all individuals who bought packages would have filled out and returned the licence forms.

Another complication, says Madstedt, is that under Swedish law he cannot prosecute the institute itself, but must identify and prove the guilt of individuals. (In contrast, the civil action now being taken by Eurodex targets the institute itself and its owner, the Swedish government.)

Madstedt admits, however, that his investigation has taken "much too long". But he says that "the fault is entirely mine", arguing that he has been too busy working on other cases. Madstedt denies reports that he has relied too much on the institute's internal inquiry, although he also agrees that "perhaps the police, and not the institute, should do more now".

Wigzell is also unhappy that Eurodex staff accompanied police during the raids. The police were not computer experts, he says, and relied on Eurodex staff to carry out the computer searches. The raids were therefore "not handled in a clear and objective manner", he says.

Several researchers at the institute also complain that the computers searched could have contained confidential medical information or data with scientific or commercial significance, and are considering starting proceedings to verify that the raid was carried out in accordance with Sweden's data protection act.

But Daniel Feldman, the president of Abacus, says that the allegations of piracy at the Karolinska institute are only "the tip of the iceberg". A total of 100,000 copies of StatView have been sold worldwide. The company estimates, on the basis of sales of handbooks on the programme, the number of support calls and references to the package in the scientific literature, that more than a million are in circulation.

Feldman is convinced that software piracy is rife in the research community. It lags behind the business world in abiding by copyright laws, he asserts, attributing this to the fact that academic institutions are "not well off", and to a culture of sharing resources. "I think that many institutes need to police this much more; it hasn't been a priority," he says.

One researcher at the Karolinska agrees that the concept of licences is foreign to many researchers: "When you buy a centrifuge it's there for everybody, you don't have licences allowing some people to use it and not others ... in this case it happens to be the Karolinska, but it could be anywhere." Since the police raids, "everyone has cleaned up their computers", he says. "We are now catching up with reality."

Other researchers argue that the high price of software adds to the temptation to copy (StatView retails at \$595). Feldman counters that Abacus offers special prices to students (who pay just \$99) and to academic users, and that it is piracy that is keeping the price of software high.

Declan Butler

\section{Ex-minister ready to share blood blame}

Ottawa. In an unusual move, Monique Begin, who was Canada's federal health minister during part of the time when the country's blood supply was infected with HIV and hepatitis C, has voluntarily waived the immunity from blame that has been called for by government lawyers.

Begin, now dean of medicine at the University of Ottawa, has said in a letter to Mr Justice Horace Krever, who is heading a commission of inquiry into the situation: "If you were to have to lay blame, I consider it my duty to take my share of responsibility."

In a recent federal court ruling, Krever won the right to include allegations of wrongdoing against some individuals, but not others, in his final report. The latter group includes 31 former health ministers and numerous senior bureaucrats. But in her letter, Begin says she was shocked to learn that three individuals who had served under her were considered blameworthy, while she and her deputy and assistant deputy ministers were not.

The three were a former executive director of the Canadian Blood Committee, a director of the Bureau of Biologics and the unpaid chairman of the National Advisory Committee on AIDS, a physician widely admired for his services to AIDS patients. Begin told Krever that these individuals - as well as her department are blameless and served Canadians "with great professionalism, unquestionable experience and total integrity".

"Justice is offended if people at the top of government in bureaucratic structures are not held responsible for their actions, but employees at less senior levels of the hierarchy are," she said. "Moreover, public ethics requires that those at the top be accountable."

Krever's report is due to be published on 30 September. But he has made it clear that it will not be ready by then because of delays caused by the court challenges to his right to lay blame. 